\title{
PEMODELAN FUNGSI TRANSFER PADA KASUS PENYAKIT JANTUNG KORONER (PJK) YANG DIPENGARUHI OLEH HIPERTENSI ESENSIAL
}

\author{
MODELING OF TRANSFER FUNCTION IN CASE CORONARY HEART DISEASE (CHD) \\ AFFECTED BY ESSENTIAL HYPERTENSION
}

\author{
Yusrina Dirayati Hermanto ${ }^{1}$, Mahmudah ${ }^{2}$ \\ Departemen Biostatistika dan Kependudukan \\ akultas Kesehatan Masyarakat Universitas Airlangga \\ Jl. Mulyorejo Kampus C Unair Surabaya 60115 \\ Alamat korespondensi: Yusrina Dirayati Hermanto \\ E-mail: yusrinadh@gmail.com
}

\begin{abstract}
Modeling of the transfer function is now widely used in research in economics and agriculture, but the use of the health sector it is still a little bit. Therefore in this study applied modeling the transfer function of CHD cases in the province of East Java. Modeling of the transfer function is a model that illustrates that the predictive value of a time series (output atauY ${ }_{\text {) }}$ ) based on past values of the time series itself and based on a time series data related to input or output $X \_t$ the series. This study uses secondary data obtained from the Health Department of East Java Province from January 2010 until August 2015 with quantitative research methods are modeling the transfer function of single input in order to get transfer function model which is applied to the cases of CHD by seeing how much influence a case essential hypertension to CHD by a certain time. The results show that there is a significant positive effect on the occurrence of CHD is equal to 0.54631. Activities for regular blood checks are needed to reduce the increasing cases of CHD due to essential hypertension.
\end{abstract}

Keywords: time series model, the transfer function single-input, CHD, hypertension 


\section{ABSTRAK}

Pemodelan fungsi transfer saat ini banyak digunakan dalam penelitian di bidang ekonomi dan pertanian tetapi penggunaan dalam bidang kesehatan dirasa masih sedikit. Oleh karena itu dalam penelitian ini diterapkan pemodelan fungsi transfer pada kasus PJK di Provinsi JawaTimur. Pemodelan fungsi transfer merupakan suatu model yang menggambarkan bahwa nilai prediksi dari suatu time series (output atau $Y_{t}$ ) berdasarkan pada nilai masa lalu dari time series itu sendiri dan berdasarkan pada suatu data time series yang berhubungan dengan input atau $X_{t}$ dengan output series. Penelitian ini menggunakan data sekunder yang diperoleh dari Dinas Kesehatan Provinsi Jawa Timur mulai bulan Januari tahun 2010 sampai bulan Agustus tahun 2015 dengan metode penelitian kuantitatif yaitu pemodelan fungsi transfer single input dengan tujuan mendapatkan model fungsi transfer yang diterapkan pada kasus PJK dengan melihat seberapa besar pengaruh kasus hipertensi esensial terhadap PJK berdasarkan kurun waktu tertentu. Hasil analisis menunjukkan bahwa terdapat pengaruh positif yang signifikan terhadap terjadinya PJK yaitu sebesar 0,54631. Kegiatan cek darah secara rutin sangat diperlukan untuk mengurangi bertambahnya kasus PJK akibat hipertensi esensial.

\section{Kata Kunci: model time series, fungsi transfer single input, PJK, Hipertensi}

\section{PENDAHULUAN}

Data merupakan deskripsi dasar dari benda, peristiwa, aktivitas dan transaksi yang direkam, dikelompokkan, dan disimpan tetapi belum terorganisir untuk menyampaikan arti tertentu (Turban, 2010). Waktu pengumpulan data dapat dibedakan menjadi tiga kategori, yaitu data cross sectional, data time series dan data panel (gabungan cross sectional dan data time series). Data time series merupakan data yang dikumpulkan dari waktu ke waktu untuk menggambarkan perkembangan suatu kegiatan atau kondisi tertentu (Supranto, 2008).

Pemodelan statistik merupakan salah satu motode statistik yang berkembang pesat seiring dengan perkembangan komputasi. Teknik pemodelan pun sangat beragam, dikembangkan dari disiplin ilmu untuk menjawab berbagai macam tujuan. Banyak metode dalam statistika yang dapat digunakan dalam melakukan pemodelan, salah satunya adalah fungsi transfer. Model fungsi transfer merupakan salah satu cara untuk menyelesaikan masalah apabila terdapat deret waktu dan terdapat hubungan sebab akibat (Makridakis, 1999).

Pemodelan fungsi transfer merupakan suatu model yang menggambarkan bahwa nilai masa depan dari suatu deret output berdasarkan pada nilai masa lalu dari data time series itu sendiri dan berdasarkan pula pada satu atau lebih input series (Aprialis,
2011). Sebagianbesar pemodelan fungsi transfer digunakan dalam penelitian di bidang ekonomi, pertanian, dan arkeologi sedangkan dalam bidang kesehatan masih jarang digunakan.

Umumnya data time series ini digunakan dalam peramalan, akan tetapi dalam penelitian ini digunakan untuk mengetahui seberapa besar pengaruh suatu kejadian yang dikaitkan dengan waktu.Pada penelitian ini metode pemodelan fungsi transfer digunakan untuk memodelkan kasus penyakit jantung koroner (PJK) di Provinsi Jawa Timur dengan variabel deret input hipertensi esensial.

Akhir-akhir ini perkembangan kondisi kesehatan masyarakat Indonesia semakin menurun dilihat dari meningginya prevalensi angka penyakit tidak menular salah satunya adalah hipertensi yang nantinya akan berpeluang besar terhadap terjadinya penyakit jantung. Hasil laporan pusat data dan informasi kementrian kesehatan RI meyatakan bahwa secara global penyakit tidak menular (PTM) merupakan penyebab kematian nomor satusetiap tahunnya adalah penyakit kardiovaskular. Penyakit kardiovaskular adalah penyakit yang disebabkan gangguan fungsi jantung dan pembuluh darah, seperti: penyakit jantung koroner, penyakit gagal jantung, hipertensi dan stroke (Kementrian Kesehatan RI, 2014). 
Tahun 2008 dapat diperkirakan sebanyak 17,3 juta kematian disebabkan oleh penyakit kardiovaskuler. Lebih dari 3 juta kematian tersebut terjadi sebelum usia 60 tahun dan seharusnya dapat dicegah. Kematian "dini" yang disebabkan oleh penyakit jantung. Kejadian ini berkisar sebesar $4 \%$ di negara berpenghasilan tinggi sampai dengan $42 \%$ terjadi di negara berpenghasilan rendah. Prevalensi penyakit jantung koroner di Indonesia tahun 2013 sebesar $0,5 \%$ atau diperkiraakan sebanyak 883.447 jiwa. Hasil dari diagnosis dokter bahwa estimasi jumlah penderita penyakit jantung koroner terbanyak adalah di Jawa Barat sebanyak 160.812 jiwa dan yang paling sedikit adalah di Maluku Utara sebanyak 1.436 jiwa. Jumlah kasus penyakit jantung koroner atau PJK terdiagnosa/gejala di Jawa Timur dapat diestimasikan sebanyak 375.127 jiwa (Riskesdas, 2013).

Komplikasi hipertensi yang menyebabkan sekitar 9,4\% kematian di seluruh dunia setiap tahunnya. Hipertensi menyebabkan setidaknya $45 \%$ kematian karena penyakit jantung dan 51\% kematian karena penyakit stroke. Kematian yang disebabkan oleh penyakit kardiovaskuler, terutama penyakit jantung koroner dan stroke diperkirakan akan terus meningkat mencapai 23,3 juta kematian pada tahun 2030 (Litbangkes RI).

Hasil utama riskesdas 2007 menggambarkan hubungan penyakit degeneratif seperti sindroma metabolik, stroke, hipertensi, diabetes militus, obesitas dan penyakit jantung koroner. Hal ini menunjukkan bahwa faktor resiko terkendali terhadap kejadian penyakit jantung koronerdiantaranya adalah penyakit hipertensi, diabetes militus, obesitas, dan sindroma metabolik. Jadi melalui data jumlah penderita penyakit tersebut dapat dilakukan seberapa besar pengaruh penaksiran jumlah untuk tahun berikutnya berdasarkan data-data penyakit yang mempengaruhi di beberapa tahun sebelumnya.

\section{METODE}

Jenis penelitian yang digunakan adalah penilitian non-reaktif yang merupakan penelitian untuk data sekunder. Penelitian ini bisa diartikan dimana sejumlah individu yang diteliti tidak sadar bahwa mereka merupakan bagian dari peilitian tetapi meninggalkan bukti dari perilaku sosial secara ilmiah.

Data yang digunakan dalam penelitian ini adalah data bulanan jumlah kasus PJK, hipertensi esensial (primer) mulai Januari 2010 sampai Agustus 2015 (sebanyak 68 plot). Pengumpulan data dilakukan dengan mencatat data bulanan jumlah kasus di Dinas Kesehatan Provinsi Jawa Timur.

Hasil dari pegolahan data kemudian dianalisis dengan menggunakan software SAS. Tujuan dari analisis data adalah membuat pemodelan pada kasus PJK menggunakan model fungsi transfer single input supaya hasil yang diperoleh dapat dimengerti serta ditarik kesimpulan untuk diberikan saran dan rekomendasi. Langkah analisis yang dilakukan yaitu Pertama, membagi data kasus PJK dan hipertensi eesensial menjadi dua yaitu data in sample dan out sample. Kedua yaitu pembentukan model fungsi transfer single input dengan mempersiapkan deret input yang stasioner, pemodelan ARIMA pada deret input, penaksiran parameter serta pngujian kesesuaian model ARIMA, prewhitening deret input dan deret output, menghitung cross correlation function serta penetapan orde $b, r, s$ untuk menduga model fungsi transfer, seleksi dan engujian parameter model fungsi transfer, penggunaan model fungsi transfer pada kasus PJK.

\section{HASIL PENELITIAN DAN PEMBAHASAN}

Penyakit jantung koroner merupakan suatu penyakit yang timbul akibat hipertensi atau meningkatnya tekanan darah melebihi batas normalnya yaitu lebih dari $140 \mathrm{mmHg}$ untuk sistoliknya dan lebih dari $90 \mathrm{mmHg}$ untuk diastoliknya (Widyastuti, 2006). Banyaknya kasus hipertensi yang tercacat di Dinas Kesehatan Provinsi Jawa Timur ini menjadi salah satu penyumbang terbesar terjadinya PJK di Provinsi Jawa Timur. Oleh karena itu untuk melihat seberapa besar pengaruh kasus hipertensi 
(esensial dan sekunder) terhadap terjadinya PJK maka dilakukan analisis menggunakan pemodelan fungsi transfer.

Data yang digunakan dalam penelitian ini merupakan data sekunder yang berasal dari Dinas Kesehatan Provinsi Jawa Timur mengenai jumlah bulanan kasus penyakit jantung koroner (PJK) sebagai variabel deret output $\left(Y_{t}\right)$, hipertensi esensial sebagai variabel deret input $\left(X_{t 1}\right)$ dari bulan Januari tahun 2010 sampai bulan Agustus tahun 2015 di Provinsi Jawa Timur. Berikut merupakan jumlah kasus PJK dan hipertensi di Provinsi Jawa Timur.

\begin{tabular}{|c|c|c|c|c|c|c|}
\hline \multirow{2}{*}{$\pi x^{\prime}=1$} & \multicolumn{6}{|c|}{$n_{n}=4$} \\
\hline & $\mathrm{ran}$ & 3001 & 352 & a 2078 & ZXV. & $2 x$ \\
\hline 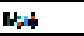 & $5 \%$ & 207 & tatks & 24 & 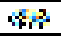 & $14+9$ \\
\hline $\sin$ & 98 & 政 & ne & स्स & $\alpha ?$ & $\Delta x$ \\
\hline arr & $m_{x}$ & Kस: & Stst & $\& 4$ & $B$ & and \\
\hline brr & M & 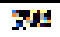 & AEF & 208 & $3 x$ & 39 \\
\hline الدئي & Sty & $\lambda s$ & Iस & $5 x$ & $\times 5$ & ז's' \\
\hline Ixs & 98 & ses & 64. & 2Es & $2 x^{x}$ & $z_{t}$ \\
\hline 46 & $x \neq 1$ & 4 4 & tad & 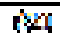 & 54 & $\min$ \\
\hline topso & $a * c$ & $15 x$ & גaks & 3) & $4 x$ & $\sin$ \\
\hline 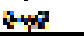 & . & $w$ & $-i m$ & 45,5 & $B$ & \\
\hline 4 & 매i & $3 \%$ & 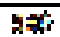 & 2रा & int & \\
\hline $\mathrm{kn}$ & by & I他 & $\because 4$ & 505 & $\langle\tilde{L} \underline{\sigma}$ & \\
\hline mon & $\mathrm{sen}$ & $\mathbf{R} \mathbf{x}_{\mathbf{L}}$ & $16 \%$ & $2 \mathrm{nd}$ & s. & \\
\hline
\end{tabular}

Gambar 1. Jumlah kasus PJK di Provinsi Jawa Timur.

\begin{tabular}{|c|c|c|c|c|c|c|}
\hline \multirow{2}{*}{ itase } & \multicolumn{6}{|c|}{ Domin } \\
\hline & 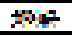 & vad & per & Kall & 494 & 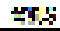 \\
\hline$x \rightarrow$ & $|k 3|$ & row & $\vec{A} \mathrm{~A} \times \mathrm{L}$ & ANa & $\mathbb{1 0} / \mathrm{A}$ & 283 \\
\hline 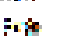 & pors & -194 & त2न्ना & 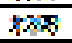 & 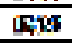 & nas \\
\hline in & ICST & 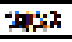 & 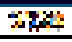 & $x_{1} \boldsymbol{\alpha}_{j}$ & LA85: & $\partial M$ \\
\hline$\infty$ & IX4 & $175 .:$ & 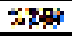 & ㄱ. & 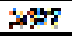 & $t a 9 x$ \\
\hline 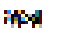 & $\lg x$ & fod & 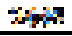 & $5 x$ & 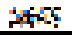 & .30 \\
\hline $\mathrm{Ler}$ & $\sqrt{8+4}$ & 1504 & $\pi A$ & $2 \times 18$ & sith1 & K4\$? \\
\hline Loll & Rath & in & 197 & 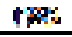 & $\pm \pi n$ & Uses \\
\hline topke & $\mathrm{wr}$ & $9 \mathrm{MS}$ & III25 & 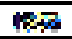 & $\pm m A$ & A1'? \\
\hline$a \times$ & 298 & 78 & $150 \mathrm{~m}$ & 6 㟧 & $\mathrm{ars}$ & \\
\hline 5 & $* \vec{w}$ & $8 \%$ & 1225 & $4 ;$ & axs & \\
\hline _ & 84 & faid & 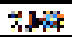 & th: & west & \\
\hline$\left[a_{k}\right.$, & tas & $2 \alpha$ & 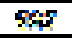 & $2 \%$ & $\Delta x$ & \\
\hline
\end{tabular}

Gambar 2. Jumlah Kasus Hipertensi Esensial di Provinsi Jawa Timur.

Langkah pertama yang harus dilakukan pada fungsi transfer adalah stasioneritas data, baik dalam varians dan means. Berikut merupakan plot time series jumlah kasus PJK di Provinsi Jawa Timur:

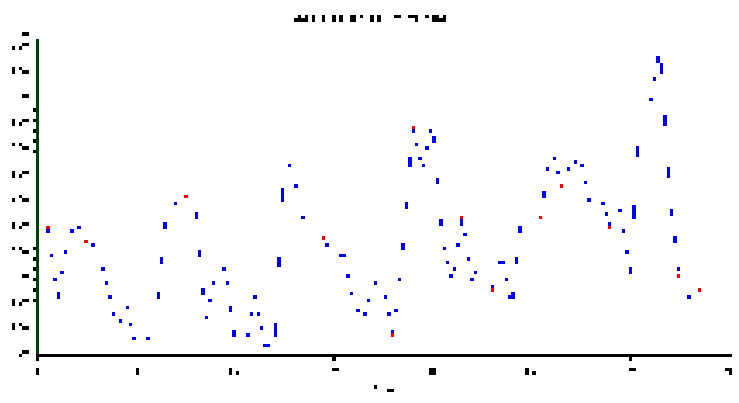

Gambar 3. Plot time series kasus PJK

Hasil time series plot pada kasus PJK menunjukkan bahwa data belum stasioner dalam varians dan means, sehingga perlu dilakukan transformasi seperti pada tabel dibawah ini:

Tabel 1. Hasil uji Box-Cox Data Jumlah Kasus Hipertensi esensial

\begin{tabular}{|c|c|c|}
\hline \multicolumn{3}{|c|}{ Hasil Transformasi Box-Cox $\left(Y_{t}\right)$} \\
\hline Lambda & R-Square & $\begin{array}{c}\text { Log } \\
\text { Likelihood }\end{array}$ \\
\hline-1.0 & 0.12 & -399.471 \\
\hline-0.5 & 0.14 & -381.129 \\
\hline 0.0 & 0.15 & -369.601 \\
\hline $0.5+$ & 0.16 & $\mathbf{- 3 6 5 . 3 0 1}$ \\
\hline 1.0 & 0.16 & -367.758 \\
\hline
\end{tabular}

Selanjutnya dilakukan uji stasioneritas data pada deret $\operatorname{input}\left(X_{t}\right)$. Berikut merupakan plot time series pada kasus hipertensi esensial:

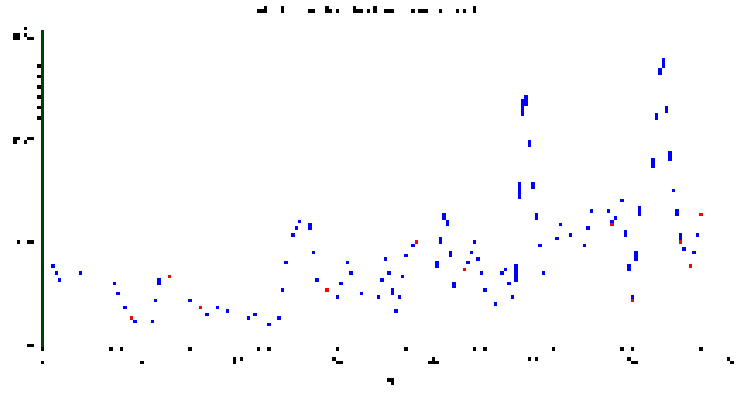

Gambar 4. Plot time series kasus hipertensi esensial

Hasil time series plot pada kasus Hipertensi esensial menunjukkan bahwa data belum stasioner dalam varians dan means, sehingga perlu dilakukan transformasi seperti pada tabel dibawah ini:

Tabel 2. Hasil uji Box-Cox Data Jumlah Kasus Penyakit Jantung Koroner (PJK 


\begin{tabular}{|c|c|c|}
\hline \multicolumn{3}{|c|}{ Hasil Transformasi Box-Cox $\left(X_{t}\right)$} \\
\hline Lambda & R-Square & $\begin{array}{c}\text { Log } \\
\text { Likelihood }\end{array}$ \\
\hline-1.0 & 0.21 & -419.191 \\
\hline-0.5 & 0.26 & -402.345 \\
\hline $0.0+$ & 0.31 & $-393.913<$ \\
\hline 0.5 & 0.33 & $-395.672 *$ \\
\hline 1.0 & 0.31 & -408.469 \\
\hline
\end{tabular}

Hasil uji Box-Cox tersebut digunakan untuk mendapatkan transformasi piihan dengan menggunakan nilai best lambda $(+) 1$ atau nilai confidence interval $(<)$ sebagai nilai yang bisa dipilih dengan tingkat kepercayaan 95\%. Berhubung transformasi yang digunakan harus sama supaya pemetaan deret input ke deret output dapay dilakukan maka diharapkan modelyang terbentuk mempunyai varian error yang kecil, maka dari itu dipilih lambda 0 sehingga trasformasi yang dterapkan adlah transformasi log, yaitu:

$$
\begin{aligned}
& T Y_{t}=\log \left(Y_{t}\right) \\
& T X_{t}=\log \left(X_{t}\right)
\end{aligned}
$$

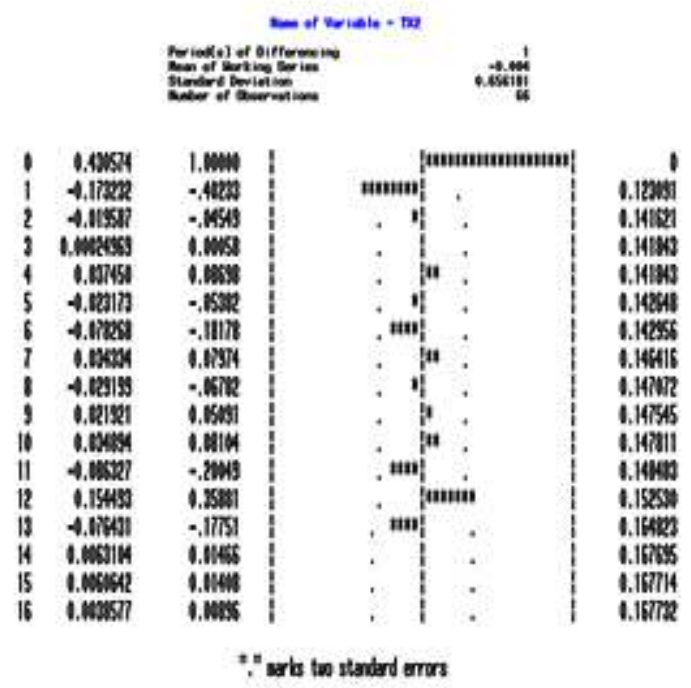

Selanjutnya dilakukan transformasi dan differencing data
Partial Autocorrelations

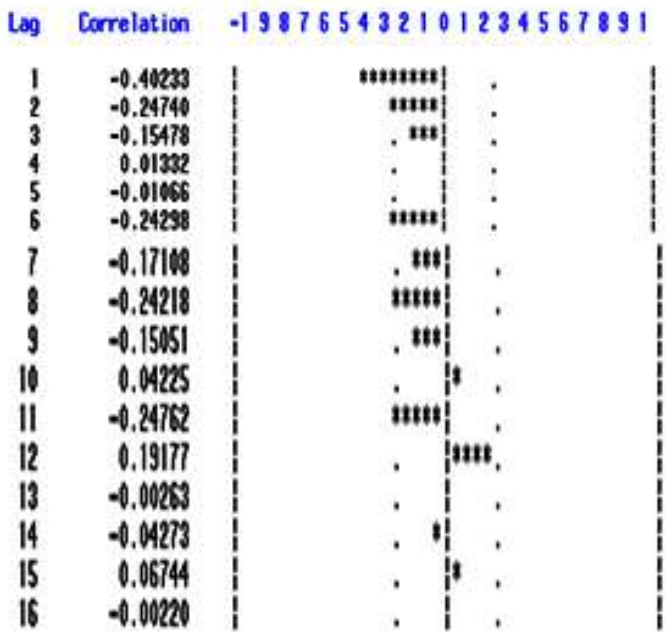

Gambar 5. Hasil Transformasi dan Differencing Plot ACF dan PACF pada Kasus Hipertensi Esensial.

Hasil differencing 1 plot ACF terpotong setelah lag-1 kemudian muncul pada lag-12, begitu juga pada plot PACF juga mengalami penurunan secara cepat setelah lag-1 kemudian muncul pada lag-6, lag-11 dan lag-12. Hal ini menunjukkan bahwa hasil dari differencing 1 sudah stasioner dalam mean dan seasonal 12 .

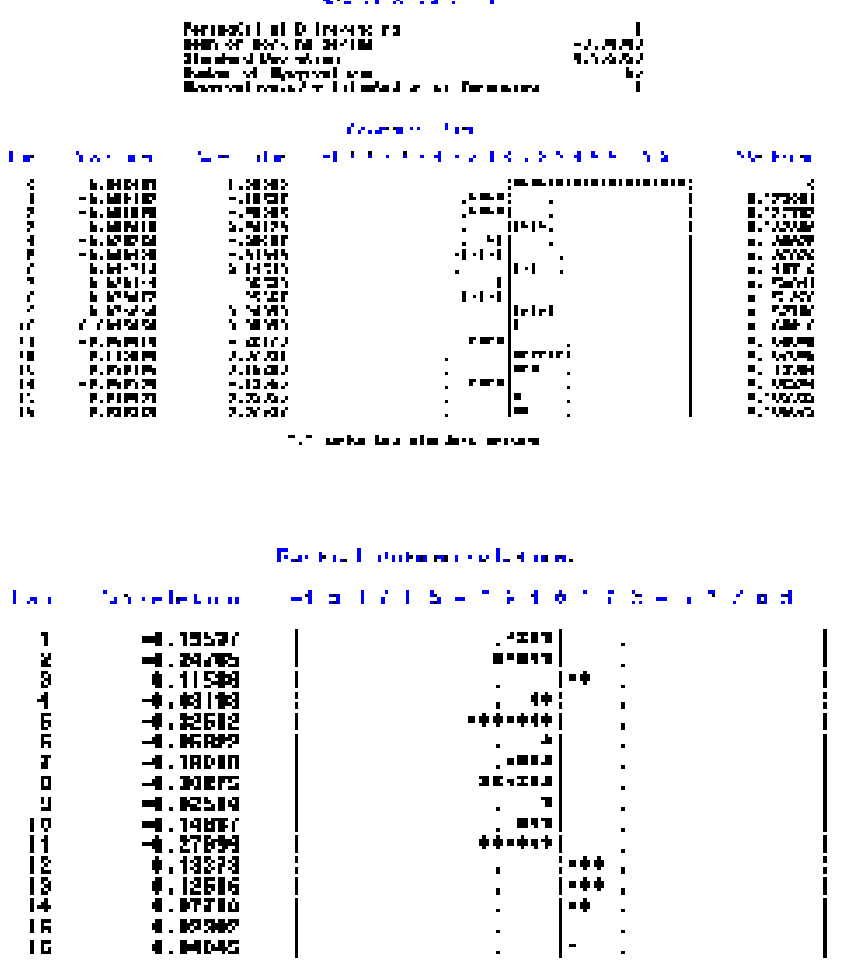


Gambar 6. Hasil Transformasi dan Differencing Plot ACF dan PACF pada Kasus PJK.

Hasil differencing 1 plot ACF muncul pada lag-5 dan lag-12, kemudian plot PACF muncul pada lag-2, lag-5, lag-8 dan lag-11. Hal ini menunjukkan bahwa hasil dari differencing 1 sudah stasioner dalam mean dan seasonal 12. Setelah deret input $\left(X_{t}\right)$ dan output $\left(Y_{t}\right)$ sudah stasioner kemudian dilakukan prewhiteningdengan melihat plot ACF dan PACF yang menunjukkn bahwa hasil indikasi pada data $\left(X_{t}\right)$ mengikuti proses ARIMA yaitu: $\operatorname{ARIMA}(0,1,1)(1,0,0)^{12}$,

$\operatorname{ARIMA}(0,1,1)(1,0,0)^{12}$,

ARIMA $([8], 1,1)(1,0,0)^{12}$,

ARIMA([6][8],1,1)(1,0,0) ${ }^{12}$,

$\operatorname{ARIMA}(0,1,1)(0,0,1)^{12}$,

$\operatorname{ARIMA}([6], 1,1)(0,0,1)^{12}$,

ARIMA([8],1,1) $(0,0,1)^{12}$ atau

ARIMA([6][8],1,1) $(0,0,1)^{12}$.

Namun pada hasil estimasi parameter hanya model yang mempunyai parameter yang signifikan saja yang ditampilkan yaitu model

$\operatorname{ARIMA}(\mathbf{0 , 1 , 1})(\mathbf{1 , 0 , 0})^{\mathbf{1 2}}$ dan

$\operatorname{ARIMA}(0,1,1)(0,0,1)^{12}$.

Langkah selanjutnya adalah seleksi model ARIMA yang diperoleh dari proses prewhitening.

Tabel 3. Seleksi Model Prewhitening HipertensiEsensial Terhadap PJK

\begin{tabular}{|c|c|c|c|c|c|c|c|}
\hline \multirow{2}{*}{ Nodel } & \multirow{2}{*}{ Var. } & \multicolumn{2}{|c|}{ Peraneler } & \multirow{2}{*}{ 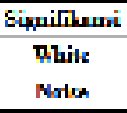 } & \multicolumn{3}{|c|}{ Revilual } \\
\hline & & Vurinase & Sig & & M1Sk & 411:- & SIII: \\
\hline 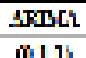 & $r_{t 2}$ & בתמט & 0,03 & 0.531 & בני0 & 963,$19 ;$ & $1,096,960$ \\
\hline$(1, a, y)^{\prime \prime}$ & $v_{s}$ & 4,53741 & Dan & $4 \times 54$ & $4,11 \% 9$ & 64, 127 & Q,A12,107 \\
\hline$\frac{\text { ARDCS }}{(0, L)}$ & $x_{i}$, & 0,72141 & 0,00 & 0.187 & $0,2 \leq 0$ & $J 04,11 \mathrm{~L}$ & $1,020,407$ \\
\hline$(0,0,1 ; z$ & $y_{r}$ & $9,18: 48$ & bou & 4 4. & 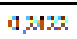 & suluss & $1,0: 4,1: 4$ \\
\hline
\end{tabular}

Tabel 3 menunjukkan bahwa model fungsi transfer antara hipertensi sekunder $\left(X_{t 2}\right)$ dan PJK $\left(Y_{t}\right)$ memiliki model prewhiteningterbaik yaitu model $\operatorname{ARIMA}(\mathbf{0 , 1}, \mathbf{1})(\mathbf{1 , 0 , 0})^{\mathbf{1 2}}$ yang mana dapat dirumuskan dari bentuk umum seasonal multiplicative model yaitu $\operatorname{ARIMA}(p, d$, q) $(\boldsymbol{P}, \boldsymbol{D}, \boldsymbol{Q})^{\boldsymbol{S}}$ dengan $p=0, d=1, q=1, P=$ $1, D=0, Q=0$, dan $S=12$ sehingga diperoleh noise model $\operatorname{ARIMA}(0,1,1)(1,0,0)^{12}$.
Tabel 4. Hasil Noise Model

\begin{tabular}{|l|r|r|c|c|}
\hline Parameter & $\begin{array}{c}\text { nilai } \\
\text { estimasi }\end{array}$ & $\begin{array}{c}\text { nilai } \\
\text { signifikan }\end{array}$ & $\begin{array}{l}\text { white } \\
\text { noise }\end{array}$ & MSE \\
\hline MA 1,1 & 0.71971 & 0.000 & 0.5381 & 0.46602 \\
\hline MA 1,1 & 0.53742 & 0.000 & 0.0654 & 0.46368 \\
\hline
\end{tabular}

Tahap pembentukan model awal tersebut dimulai dengan menghitung Cross Corelation Function (CCF) atau disebut dengan perhitungan korelasi silang. Hasil dari perhitungan korelasi silang antara hipertensi esensial dengan penyakit jantung koroner sebagai berikut:

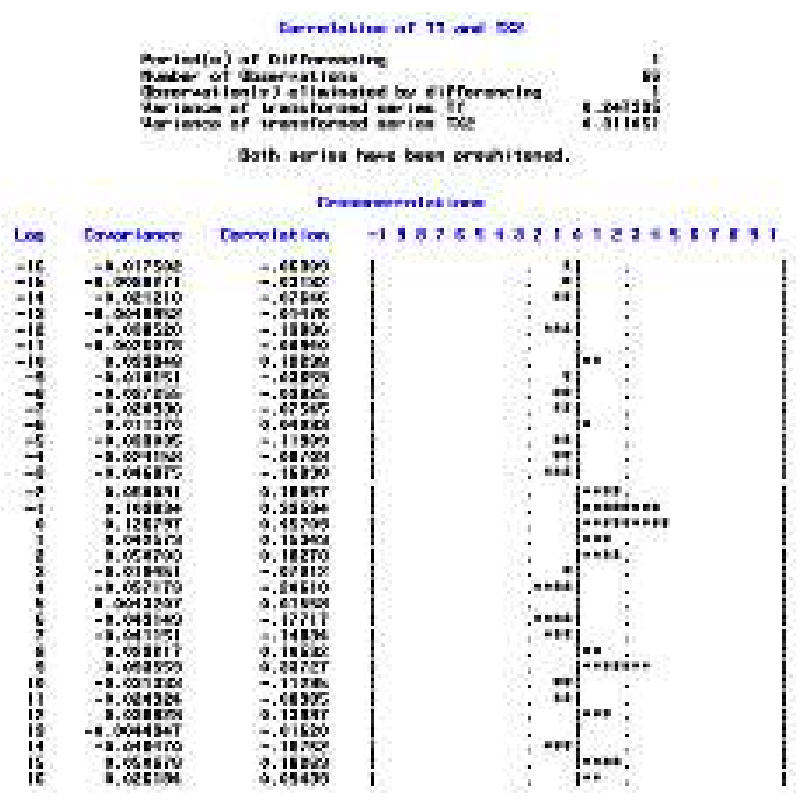

Gambar 7. Fungsi Korelasi Silang

Dilihat dari hasil output cross correlation antara hipertensi esensial dengan PJK diperoleh gambaran nilai CCF pertama kali muncul pada lag-0 sehingga nilai $b=0$, kemudian nilai CCF memiliki pola menurun pada lag-0 sehingga nilai $s=0$ dan plot CCF terpotong pada beberapa lag sehingga $r=0$. Selanjutnya adalah penaksiran parameter model fungsi transfer. Penaksiran parameter model fungsi transfer singleinput dengan model ARIMA diperoleh hasil parameter model bersama dengan pengujian Goodness of fit. Berikut merupakan hasil seleksi pemodelan hipertensi esensial terhadap PJK yaitu: 
Tabel 5. Penaksiran Parameter Model

\begin{tabular}{|c|c|c|c|c|c|c|}
\hline \multirow{2}{*}{$\begin{array}{l}\text { Mlodel } \\
\text { Funngsi } \\
\text { Transter }\end{array}$} & \multicolumn{2}{|c|}{ Faramcter } & \multirow{2}{*}{ 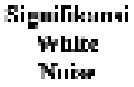 } & \multicolumn{3}{|c|}{ Kesdonall } \\
\hline & Fydimuxi & in & & MSFF & AIC & SEC: \\
\hline 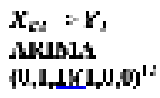 & $n, \leqslant 17 \leq 2$ & nLono & ก, & 0,1752 & $7,549 \mathrm{in}$ & 84,1156 \\
\hline 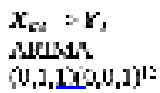 & $n, k 14 \%$ & $n \in 00$ & nol 019 & 0 & Thanas & 246392 \\
\hline
\end{tabular}

Pada output estimasi parameter ini, model fungsi transfer antara $X_{t}$ dan $Y_{t}$ memiliki noise model terbaik yaitu model $\operatorname{ARIMA}(\mathbf{0 , 1}, \mathbf{1})(\mathbf{1 , 0 , 0})^{\mathbf{1 2}}$ dengan orde bobot impuls yaitu $b=0, r=0$, dan $s=0$ yang mana dapat dirumuskan dari bentuk umum seasonal multiplicative model yaitu $\operatorname{ARIMA}(\boldsymbol{p}, \boldsymbol{d}, \boldsymbol{q})(\boldsymbol{P}, \boldsymbol{D}, \boldsymbol{Q})^{\boldsymbol{S}}$ dengan $p=0, d$ $=1, q=1, P=1, D=0, Q=0$, dan $S=12$. Sehingga diperoleh model fungsi transfer single input $\left(X_{t}\right)$ dengan noise model $\operatorname{ARIMA}(\mathbf{0 , 1}, \mathbf{1})(\mathbf{1 , 0 , 0})^{\mathbf{1 2}}$. Berikut merupakan noise model yang diperoleh:

Tahap akhir dari pemodelan fungsi transfer adalah memilih model terbaik. Model yang didapat adalah sebagai berikut:

$$
\begin{gathered}
y_{t}=v(B) x_{2, t}+n_{t} \\
y_{t}=0,54631 x_{2, t}+\frac{(1-0,81782 B)}{\left(1-0,31026 B^{12}\right)} a_{t} \\
\left(Y_{t}-Y_{t-1}\right)=0,54631\left(X_{2, t}-X_{2, t-1}\right) \\
+\frac{(1-0,81782 B)}{\left(1-0,31026 B^{12}\right)} a_{t}
\end{gathered}
$$

\section{PEMBAHASAN}

Berdasarkan hasil analisis dengan menggunakan pemodelan fungsi transfer maka diperoleh hasil pemodelan yakni pemodelan menggunakan single input pada kasus hipertensi esensial terhadap PJK.

Model fungsi transfer single input ini menjelaskan bahwa jika perubahan hipertensi sekunder pada bulan ini dengan bulan sebelumnya mengalami peningkatan, maka perubahan PJK pada bulan ini dengan bulan sebelumnya akan mengalami peningkatan sebesar 0,546321 , sebaliknya jika perubahan hipertensi sekunder pada bulan ini dengan bulan sebelumnya mengalami penurunan, maka perubahan PJK pada bulan ini dengan bulan sebelumnya juga akan mengalami penurunan sebesar 0,546321.

Schrier (2000) juga menyebutkan bahwa persentase hipertensi esensial di
Indonesia sebesar 95\% sedangkan pada hipertensi sekunder hanya 5\%. Hipertensi esensial (primer) merupakan hipertensi yang tidak diketahui penyebabnya, berbeda dengan hipertensi sekunder yang dapat secara jelas diketahui penyebabnya. Hipertensi yang paling banyak terjadi adalah hipertensi yang tidak menimbulkan gejala, sementara tekanan darah terus menerus meningkat dalam jangka waktu yang cukup lama sehingga dapat menimbulkan komplikasi.

Hal ini bisa dikatakan bahwa hipertensi esensial menjadi salah satu penyebab atas meningkatnya jumlah PJK (Sidabutar, 2009). Hasil Riset Kesehatan Dasar tahun 2010 menyebutkan bahwa Jawa Timur merupakan provinsi yang menempati peringkat pertama penyandang prevalensi hipertensi tertinggi di Indonesia yang kemudian disusul dengan provinsi Bangka dan Jawa Tengah.

\section{SIMPULAN DAN SARAN}

Data PJK dan hipertensi esensial tidak stasioner dalam varians dan means, oleh karena itu dilakukan transformasi dan differencing sehingga diperoleh model $\operatorname{ARIMA}(\mathbf{0 , 1}, \mathbf{1})(\mathbf{1}, \mathbf{0 , 0})^{\mathbf{1 2}}$ atau dapat dituliskan dalam bentuk persamaan sebagai berikut:

$$
\begin{aligned}
\left(Y_{t}-Y_{t-1}\right)= & 0,54631\left(X_{2, t}-X_{2, t-1}\right) \\
& +\frac{(1-0,81782 B)}{\left(1-0,31026 B^{12}\right)} a_{t}
\end{aligned}
$$

Artinya terdapat pengaruh positif yang signifikan dari hipertensi esensial terhadap PJK sebesar 0,54631pada bulan (periode) yang sama. Dari hasil penelitian tersebut saran yang dapat disampaikan yaitu apabila menggunakan pemodelan fungsi transfer atau pemodelan lainnya maka asumsi yang disyaratkan harus diperhatikan dengan betul karena akan berpengaruh pada hasil pemodelan yang diperoleh. Selain itu kegiatan cek tekanan darah rutin supaya bisa mengkontrol status tekanan darah sehingga bisa mengurangi atau mencegah bertambahnya kasus PJK karena hipertensi. 


\section{DAFTAR PUSTAKA}

Aprialis. 2011. Perbandingan Model Fungsi Transferdan ARIMA Studi Kasus Modelantara Curah Hujan denganKelembaban Udara. Skripsi. UIN Syarif Hidayatullah Jakarta.

Badan Penelitian Dan Pengembangan Kesehatan. 2013. Riset Kesehatan Dasar [pdf]. Diakses dari www.dinkes.bantenprov.go.id pada 18 Maret 201615.52 WIB.

Dinas Kesehatan Provinsi Jawa Timur. 2012. Profil Kesehatan Provinsi Jawa Timur tahun 2012. Diakses dari depkes.go.id pada 22 Maret 2016 10.44 WIB.

Dirpan, Andi. 2007. Metode peramalan kuantitatif dengan software. [pdf] diakses dari repository.unhas.ac.id pada 16 April 2016 13:51 WIB.

Makridakis, S., Wheelwright, S.C., dan McGee, V.E. 1999. Metode dan Aplikasi Peramalan $2^{\text {nd }}$ eds. Jakarta: Binarupa Aksara.

Supranto, J. 2008. Statistik: Teori dan Aplikasi. $7^{\text {nd }}$ eds. Jakarta: Erlangga.

Turban, E., Shandra, R.E., dan Delen, D. 2010.Decision Support and Business Intelligence Systems. Jakarta: Amazon WD.

Wei, W.W.S. 2006. Time Series Univariate and Multivariate Methods. $2^{\text {nd }}$ ed. United States of America: Pearson Education.

WHO. 2011. Deaths from Coronary Heart

Disease. Diakses dari

http://www.searo.who.int/topics/cardiovasc ular_diseases/en/ pada tanggal $24 \mathrm{Mei}$

2016. 10:39. 